\title{
Predicting the Condition of Agricultural Lands in Pati Regency to Make Sustainable Food Providing Against the Future
}

\author{
Eva Banowati ${ }^{1, *}$ Ariyani Indrayati ${ }^{2,}$ Atno ${ }^{3,}$ \\ Yuria Sari ${ }^{4}$, Mitha Fitria Anggraini ${ }^{5}$, Aprilia Indriyani ${ }^{6}$ \\ ${ }^{12456}$ Department of Geography, Faculty of Social Science, Universitas Negeri Semarang \\ ${ }^{3}$ Department of History, Faculty of Social Science, Universitas Negeri Semarang \\ "Corresponding author.Email: evabanowatigeografi@mail.unnes.ac.id
}

\begin{abstract}
The food crop agricultural sector in Pati Regency in 2019 succeeded in producing more than 592 thousand tons of rice with a harvest area of 99,453 hectares (BPS, 2021). This achievement must be increased without overexploiting the land. Field data for 2020 shows a population of $1,324,188$ people, a population growth rate of $0.58 \%$. Farmers apply a sustainable agricultural system. These findings were analyzed using the calculation of the carrying capacity of agricultural land developed from population pressure (Soemarwoto, 1985). Furthermore, it is described as an explanation of the calculation results. The results showed that the carrying capacity of agricultural land in 2020 is worth 1.35 , meaning that it can provide rice for its residents, even a surplus. Indicates high land productivity. Meanwhile, the prediction of the carrying capacity of agricultural land in 2030 will be 1.28 which indicates a decrease in value of 0.07 but it is still able to meet the food needs of the population. The application of the concept of sustainable agriculture by farmers needs to be carried out and supported by various policies from the local government so that the sustainability of agricultural conditions in Pati Regency is maintained.
\end{abstract}

Keywords: Carrying Capacity, Food, Population Pressure.

\section{INTRODUCTION}

Food is one of the basic human needs needed to carry on life. Fulfilling food needs is also related to efforts to improve the quality of public health, so that later human resources who have strong and superior competitiveness will be obtained [6]. Agricultural land as a place to produce food commodities has decreased. The increase in population coupled with the development activities that have been carried out has taken many of the functions of agricultural land as a producer of foodstuffs into other uses such as settlements, offices, and so on[4]. The availability of food that is smaller than the need will cause economic instability in a country. Various social and political upheavals can occur if food security is disrupted and has the potential to endanger national stability (Ismet, 2007 in[7]. Food security is one of the challenges facing the Indonesian nation in the future, due to the increase in population from time to time. The agricultural sector must be optimized to meet domestic food needs and avoid food imports from other countries. Food self-sufficiency needs to be realized to meet the food needs of one region and export to other regions.

Agriculture is still an economic activity that is favored by the people of Indonesia because of the supportive landscape conditions. Located in a tropical region, with two seasons that continue to change and fertile land conditions and the social conditions of rural communities, the agricultural sector still exists today. Indonesia is supported by many factors, including natural resources that are built up from the world's two young mountains so that many volcanoes can rejuvenate the soil, climatic and weather conditions as well as processes of erosion, sedimentation, weathering of rocks that make soil formation take place quickly[2]. The agricultural sector has been the backbone of the economy for a long time, but of course, nature as a resource provider has limits. The ability of nature to support agricultural activities needs to be addressed by humans so that there is sustainability in the supply of foodstuffs 
According to Law No. 32 of 2009 concerning Environmental Management, the carrying capacity of the environment is the ability of the environment to support the lives of humans and other living creatures. Each ecosystem has its ability to support life, including the provision of food for living things. The percentage of land that can be used for agriculture and the number of agricultural yields per unit area and time become benchmarks in calculating the carrying capacity of agricultural land. The greater the percentage of land that can be used as agricultural land, the greater the carrying capacity of the area's land (Otto, 1983 in [3].

In the provision of food, increasing the population is a serious problem if it is not followed by a sustainable increase in food production. Then, the availability and quality of land are some of the factors that influence the amount of food production. Fixed land area, while the population continues to increase causing massive population pressure on land. Pati Regency is one of the districts in Central Java that has potential in the agricultural sector. The food crop agricultural sector in Pati Regency in 2019 succeeded in producing more than 592 thousand tons of rice with a harvest area of 99,453 hectares[1]. This achievement must be increased without overexploiting the land. This achievement must be increased along with the inevitable population growth, of course without overexploiting the land.

Field data for 2020 shows a population of $1,324,188$ people, with a population growth rate of $0.58 \%$. With the increasing population that occurs every year in Pati Regency, the pressure on land needs is also increasing. Agricultural land is threatened by its existence because it has the potential to be converted. Therefore, a study is needed relating to the carrying capacity of agricultural land in Pati Regency to determine or measure the condition of agricultural land to create a sustainable food supply in the future.

\section{METHODOLOGY}

This research was conducted in Pati Regency, Central Java Province. The data used in this research are primary data and secondary data obtained through direct observation and interviews in the field, literacy studies, and documentation. Field data for 2020 shows a population of $1,324,188$ people, a population growth rate of $0.58 \%$. This study was analyzed using the calculation of the carrying capacity of agricultural land developed from population pressure (Soemarwoto, 1985 in Muta'ali, 2015). This calculation compares the farmer population with weighted agricultural land to the area of land for a decent living and the income of non-agricultural farmers. Furthermore, it is described as an explanation for the calculation results.
Soemarwoto (1989) states that population pressure is caused by population growth in rural areas which results in a decrease in the ratio of land to population (man-land ratio). Some of the basic variables that determine the sensitivity of the population to agricultural land (Mutaali, 2012) are as follows:

- The number of inhabitants in which the definition of the population depends on agriculture, namely farmers and their families

- Extent of agricultural land available or cultivable

- The desired standard of life

- Agricultural systems practiced

- Income that comes from outside the farm.

The above variables can be shown mathematically as follows:

Population pressure at any given moment $(\mathrm{Po})$ :

$$
T P=\left(1-a_{t}\right) \cdot Z_{t} \frac{f_{t} \cdot P_{\mathrm{o}}}{\beta \cdot L_{t}}
$$

Prediction of future population pressure $(\mathrm{Pt})$ :

$$
T P=\left(1-a_{t}\right) \cdot Z_{t} \frac{f_{t} \cdot P_{\mathrm{o}}(1+\mathrm{r})^{\mathrm{t}}}{\beta \cdot L_{t}}
$$

Information:

$\mathrm{TPt}=$ Population pressure on agricultural land $\mathrm{t}=$ period of calculation time

$\mathrm{Zt}=$ area of land needed to support a farmer's life at a desired or feasible level (ha / person)

$\mathrm{ft}=$ percentage of farmers in the population

$\mathrm{PO}=$ size of population at reference time (person)

$\mathrm{Lt}=$ area of agricultural land in the area concerned

at $=$ percentage of non-agricultural income $(0<\mathrm{a}<\mathrm{t})$

$\beta=$ share of land benefits enjoyed by farmers or tenants $(0<b<1)$ or agricultural land used (cultivated)

Based on this formula, the interpretation of the value of population pressure on agricultural land is as follows:

- TP> 1, population pressure occurs, the carrying capacity of agricultural land is exceeded (overpopulation)

- TP $<1$, there is no population pressure, still able to support the existing population (underpopulation)

The carrying capacity of agricultural land

In this formula it is stated that the amount of environmental carrying capacity is 1 / TP or it can be stated that the environmental carrying capacity (DDL) is inversely proportional to population pressure:

$\mathrm{DDL}=1 / \mathrm{TP}$ 


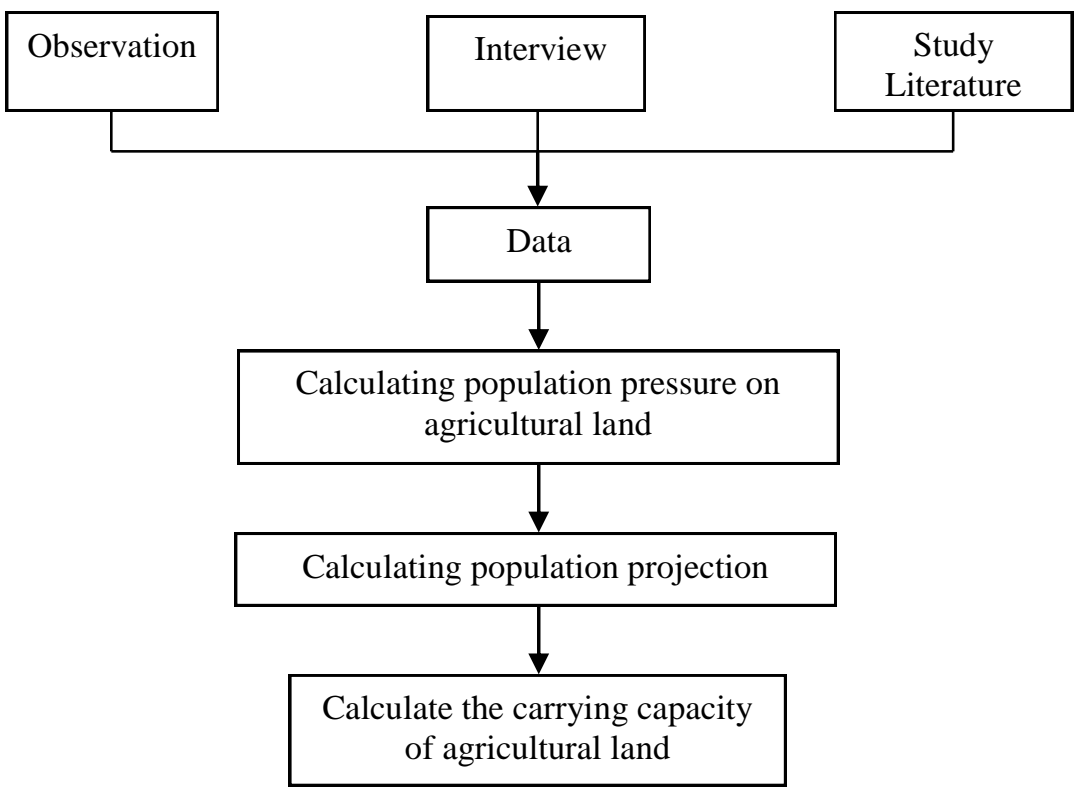

Source:Banoeati,dkk. 2021

Figure 1. Research Flowchart

\section{RESULTS AND DISCUSSION}

Pati Regency is one of the regencies in Central Java which has potential in agriculture. Apart from being supported by climatic conditions, land in Pati Regency also plays a role in supporting the agricultural sector. Based on the 2017 land use map, rice fields in Pati Regency still dominate land use in Pati Regency. The agricultural sector still dominates most of the population's activities.

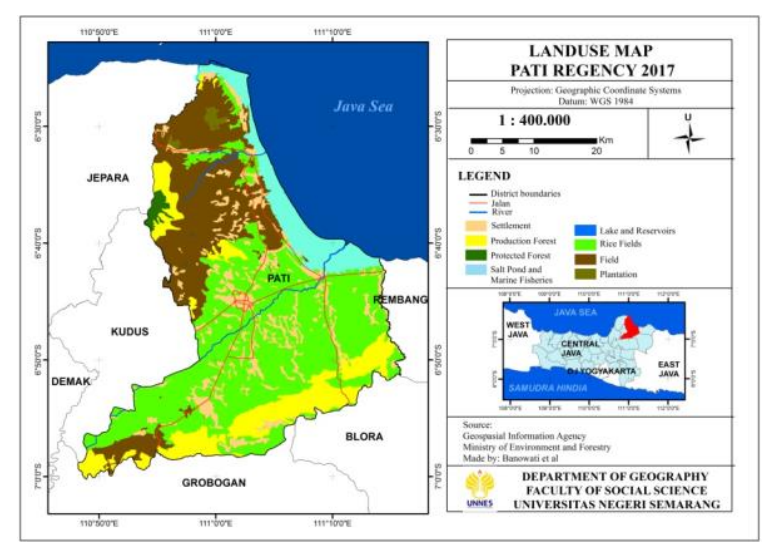

Fig 2. Landuse Map of Pati Regency

Population pressure in 2020:

$$
\begin{aligned}
T P & =\left(1-a_{t}\right) \cdot Z_{t} \frac{f_{t} \cdot P_{\mathrm{o}}}{\beta \cdot L_{t}} \\
& =(1-0,35) \cdot 0,50 \frac{0,103 \cdot 1 \cdot 324 \cdot 188}{0,50 \cdot 119 \cdot 613} \\
& =(0,65) \cdot 0,50 \frac{136 \cdot 391,364}{59 \cdot 806,5}
\end{aligned}
$$

$$
=0,74
$$

The results of the calculation of population pressure on land carrying capacity in 2020, obtained a land carrying capacity value of 0.74 . The value of TP $<1$ so that in 2020 in Pati Regency there will be no population pressure on agricultural land, or agricultural land is still able to support the existing population (underpopulation) in Pati Regency.

Carrying capacity of agricultural land in 2020:

$$
\begin{aligned}
\mathrm{DDL} & =1 / \mathrm{TP} \\
& =1 / 0,74 \\
& =1,35
\end{aligned}
$$

Based on the results of the calculation of the carrying capacity of agricultural land in Pati Regency in 2020, the results show that the value of the carrying capacity of the land is 1.35. This shows that the district of starch can still meet the food needs of its population.

The projected population of Pati Regency 2030 :

$$
\begin{aligned}
& \mathrm{Pn}=\mathrm{Po}(1+\mathrm{r}) \mathrm{t} \\
& \mathrm{Pn}=\text { Number of population in the nth year } \\
& \mathrm{Po}=\text { Number of residents in the initial year } \\
& \mathrm{r} \quad=\text { Population growth rate } \\
& \mathrm{t} \quad=\text { time of year (projection period) }
\end{aligned}
$$

$$
\begin{aligned}
\mathrm{P} 2030 & =\mathrm{P} 2020(1+0,0058) 10 \\
& =1.324 .188 \times(1,0058) 10 \\
& =1.324 .188 \times 1,0595 \\
& =1.402 .977 \text { jiwa }
\end{aligned}
$$

The results of the calculation of the population projection of the Pati Regency for the next 10 years (2030) show that the population of Pati Regency in 
2030 is $1,402,977$ people. The results of the calculation were carried out using geometric population projections with population data in 2020 of $1,324,188$ people and a population growth rate of 0.0058 .

Predicted population pressure in 2030:

$$
\begin{aligned}
T P & =\left(1-a_{t}\right) \cdot Z_{t} \frac{f_{t} \cdot P_{\mathrm{o}}(1+\mathrm{r})^{\mathrm{t}}}{\beta \cdot L_{t}} \\
& =(1-0,35) \cdot 0,50 \frac{0,103 \cdot 1 \cdot 402 \cdot 977}{0,50 \cdot 119 \cdot 613} \\
& =(0,65) \cdot 0,50 \frac{144 \cdot 506,631}{59 \cdot 806,5} \\
& =0,78
\end{aligned}
$$

Based on the results of the calculation of population pressure on the carrying capacity of agricultural land for the next 10 years (2030), it is found that the value of the carrying capacity of the land is 0.78 . The value of TP $<1$ means that this year in Pati Regency there is no population pressure on agricultural land, or agricultural land is still able to support the existing population (underpopulation) in Pati Regency. In 2030, Pati Regency can still meet the food needs of its population. The results of the calculation show that there has been an increase in population pressure on agricultural land by 0.04 which occurred in a period of 10 years, namely in the years 2020-2030.

Carrying capacity of agricultural land in 2020:

$$
\begin{aligned}
\mathrm{DDL} & =1 / \mathrm{TP} \\
& =1 / 0,78 \\
& =1,28
\end{aligned}
$$

Based on the calculation of the carrying capacity of agricultural land in Pati Regency in 2030, it is found that the value of the carrying capacity of the land is 1.28. This shows that the district of starch can still meet the food needs of its population.

The results showed that the carrying capacity of agricultural land in 2020 is worth 1.35, meaning that it can provide rice for its residents, even surplus or sold to other areas. Indicates high land productivity. The prediction of the carrying capacity of agricultural land in 2030 shows a value of 1.28. There was a decline in the value of the carrying capacity of agricultural land that occurred in Pati Regency by 0.07 in 10 years, namely 2020-2030. Although the results of calculations in 2030 still show that in 2030 Pati District can still meet its food needs, what we need to pay attention to is that population pressure on agricultural land has increased from year to year. The application of the concept of sustainable agriculture by farmers needs to be carried out and supported by various policies from the local government to be able to reduce the dependence of the population on agricultural land and maintain the sustainability of agricultural activities in Pati Regency.

Based on the results of the research conducted, the relationship between population pressure and land carrying capacity is that the higher the population pressure on agricultural land, the smaller the value of the land carrying capacity, and conversely the smaller the population pressure on agricultural land, the greater the value of the carrying capacity of the land. The results of the calculations carried out show that the carrying capacity of agricultural land for 10 years can meet the food needs of the people of Pati Regency.

In agricultural land management, soil fertility is also influenced by the use of chemical substances such as chemical fertilizers and pesticides. In terms of the procurement of chemical fertilizers, the Government assists in the form of urea fertilizer subsidies to farmers.Fertilizer subsidies provided are very helpful for farmers in increasing agricultural production. Farmers use urea fertilizer for an average of 350 $\mathrm{kg} / \mathrm{ha}$. This is following the dosage recommended by the government, namely $200 \mathrm{~kg} / \mathrm{ha}$ for low productivity, $250-300 \mathrm{~kg} / \mathrm{ha}$ for medium productivity, and $300-400 \mathrm{~kg}$ for high productivity. However, what still needs to be considered is the use of pesticides that are not properly measured due to the large number of pests that will also kill soil decomposing animals, which it is feared that in the future it will have an impact on decreasing soil fertility.

\section{CONCLUSION}

The results showed that the carrying capacity of agricultural land in 2020 is worth 1.35, meaning that it can provide rice for its residents, even surplus or sold to other areas. Indicates high land productivity. Meanwhile, the prediction of the carrying capacity of agricultural land in 2030 will be 1.28 . There was a decrease in the carrying capacity value of 0,07 . The application of the concept of sustainable agriculture by farmers needs to be carried out and supported by various policies from the local government so that the sustainability of agricultural conditions in Pati Regency is maintained.

\section{ACKNOWLEDGMENTS}

Researchers would like to thank the Rector of Universitas Negeri Semarang, Prof. Dr. Fathur Rokhman M.Hum, Chair of the Universitas Negeri Semarang Service and Research Institute, the Dean of the Faculty of Social Science, and all parties involved in this research including farmers in Pati Regency who have supported and assisted this research activity. 


\section{REFERENCES}

[1] Central Bureau of Statistics (BPS) Pati Regency in 2020

[2] Banowati, Eva., Sriyanto., and Findayani, Aprilia. (2021). Development of The Livelihoods of The Agrarian Population in The Pati Regency. In Rumah Ilmu Karakter, Kreativitas Dan Inovasi Vol. 2. Semarang:UNNES Press.

[3] Harini, R., Ariani, R. D., Fistiningrum, W., \& Ariestantya, D. (2019, April). Economic Valuation Of Mangrove Management In Kulon Progo Regency. In IOP Conference Series: Earth and Environmental Science (Vol. 256, No. 1, p. 012036). IOP Publishing.

[4] Jocom, S. G. (2017). Study of the Supporting Capacity of Agricultural Land in Supporting Food Self-Sufficiency in South Minahasa District. Agri-Socioeconomics, 13(1), 11-24.

[5] Law No. 32 of 2009 on Environmental Management

[6] Putri Wiyanti, D. A. N. A. R. J. A. T. I., \& Hari Purnomo, N. U. G. R. O. H. O. (2018). Prediction of Staple Food Needs for Rice and Corn on Changes in Population in 2018-2038 in Pasuruan Regency. Swara Bhumi, 5 (7).

[7] Rohman, A., \& Maharani, A. D. (2017). Projection of the need for rice food consumption in the Special Region of Yogyakarta. Jurnal Caraka Tani: Journal of Sustainable Agriculture. Universitas Sebelas Maret, 29. 